Dept. of Anat., Kyoto Prefectural Med. College (Director: Prof. Dr. H. NODA) and Lab. of Macromolec. Biol. and Electr. Microsc., Osaka City Univ. Med. School

(Head: Lecturer Dr. T. FUJIWARA).

\title{
Electron Microscopic Observation on the Neurosecretory Granules in the Pituitary Posterior Lobe of Dog. *
}

\author{
(Contributions to the Comparative Histology of the Hypothalamo- \\ hypophysial System. 30th report.) \\ 後葉（犬）に和ける神経分泌顆粒の電子顕微鏡所見.
} （視床下部下垂体系の比較組織学的研究。第30報.）

\section{Hisao FUJITA 藤田尚男.}

(Received February 12, 1957.)

With the introduction of GOMORI's CHP method, studies on the hypothalamo-pituitary neurosecretory system have come to receive a great deal of attention. Various aspects of the neurosecretory substance have been persued by many investigators. SCHIEBLER (1951), GOSLAR (1952), HIRAOKA and IMOTO (1955) and GOSLAR and TISCHENDORF (1955) have studied this substance concerning its staining properties. SCHIEBLER (1951), BARRNETT and SELIGMAN (1952, 1954), IMOTO (1955, 1956) have made observations from the histochemical standpoint, and HILD and ZETLER (1951-1953) from the pharmacological point of view. However, only a few studies have been reported concerning the submicroscopic structure of the neurosecretory substance. The results obtained from my electron-microscopic observations on the posterior lobe of dog will be described in the present paper.

\section{Material and Method.}

Five adult dogs were used. Immediately after Ravonal (thiopental sodium) injection, the skull was opened and the animal was killed by section of both carotid arteries. The posterior lobe of the removed hypophysis was cut in pieces of about $1 \mathrm{cmm}$ and fixed for $1-4$ hours in fluid consisting of equal amount of $2 \%$ osmic acid solution and veronal or phosphor buffer solution of $\mathrm{pH}$ 7.4. Time required before fixation after the death of the animal was $2-5$ minutes, the temperature, 5-

* Thanks are due to Prof. K. Suzuki, Dept. of Anat., Osaka City University, for facilities given by him. 
$10^{\circ} \mathrm{C}$. After dehydration with alcohol, the tissue was embedded in 8:2 mixture of n-butyl-methacrylate and methyl-methacrylate. The observation was made on electron-microseopic sections prepared with the ultramicrotome of J. U. M. 3. type.

\section{Observation and Consideration.}

\section{A. Observation on the neurosecretory granules.}

Round, oval and cylindrical (width, 1-5 $/$ ) light toned areas enclosed by dark membranes or capsules are observed throughout the posterior lobe. A great number of dark toned granules spread within these areas can be observed (Figs. 1, 2 and 3). The capsule surrounding these light toned areas is observed to be composed of a double membrane; each of the light area being surrounded completely or incompletely by such capsule. Along the corners of the areas surrounded by these eapsules, pituicytes are occasionally observed. The process of the pituicyte is observed to be situated close to the capsule, but never penetrates the membrane to invade into the light area. Hence, it is evident that the process is situated outside these areas. The right half of Fig. 3 shows findings believed to be the diagonal section of a nerve fiber. In view of the fact that an oval area appears due to the disappearance of the longitudinal bundle of fine filaments (supposed to be either myelin sheath or protoneurofibrils of the nerve fiber) which appear to have been pushed aside, this oval area is assumed to be in the diagonal section of a nerve fiber, in other words the interior portion of a nerve fiber. Also this area is found to be surrounded by the capsule, containing within it some

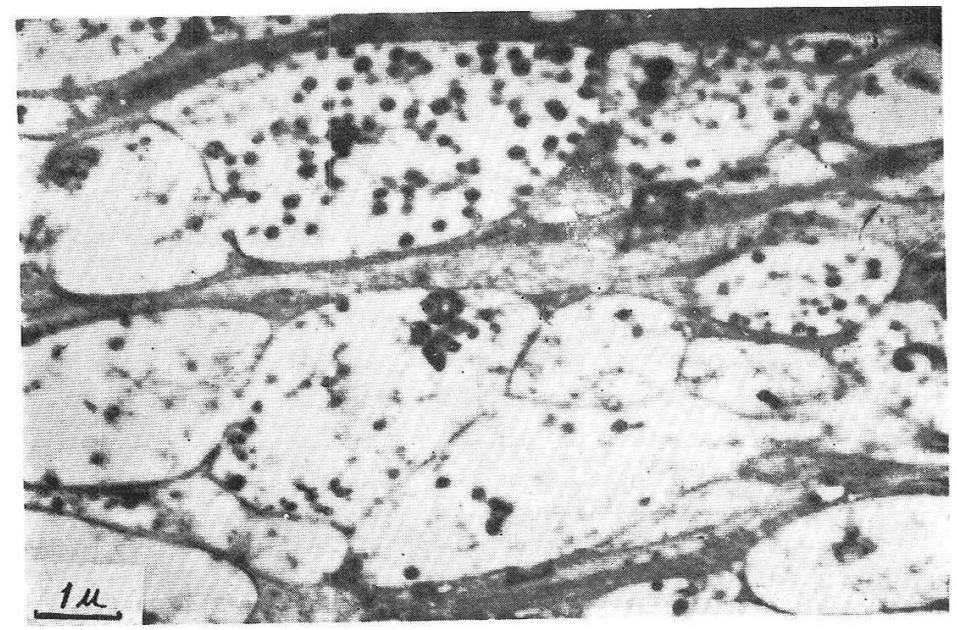

Fig. . 1 


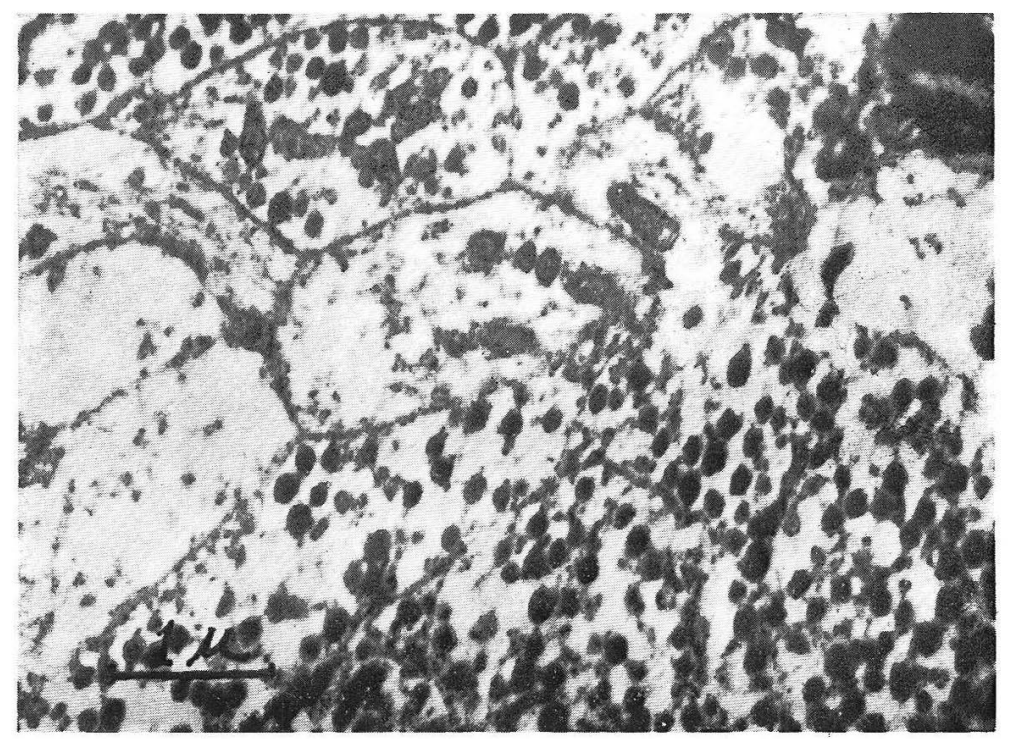

Fig. 2

dark toned granules, objects of high electron density. So this light oval area observed in the nerve fiber has structures identical to those seen throughout the posterior lobe as are shown in Figs. 1 and 2. Furthermore in Fig. 2, in some areas surrounded by the double membrane, bacilliform mitochondria-like figure possessing the cristae mitochondriales can also be seen simultaneously with the granules (fig. 2). We may conclude from these findings that some of the round, oval or cylindrical areas with light tone belong to the interior portion of the nerve fiber. This, however, is not enough to point out that all the light areas observed in Figs. 1 and 2 are actually the interior of the nerve fiber.

Now in Fig. 3 many fine filaments running longitudinally in the nerve fiber disappear gradually as if they were pushed aside, and following this an oval area is seen enclosed by a double membrane. Then question arises as to whether these longitudinal filaments are myelin sheath or the protoneurofibrils. First, if this be considered as the myelin sheath, there must be some protoneurofibrils and occasionally mitochondria present in the light toned oval area. However, only a few black points and irregularly arranged linear or dotted structures are observable there. But in case these irregular structures be considered as protoneurofibrils, the findings may be anyhow explainable. Next, if the longitudinal fine filaments be considered as protoneurofibrils, it may be supposed that this oval area surrounded by the membrane had descended as a whole mass in the interior of the sheathless nerve fiber driven by the proto- 


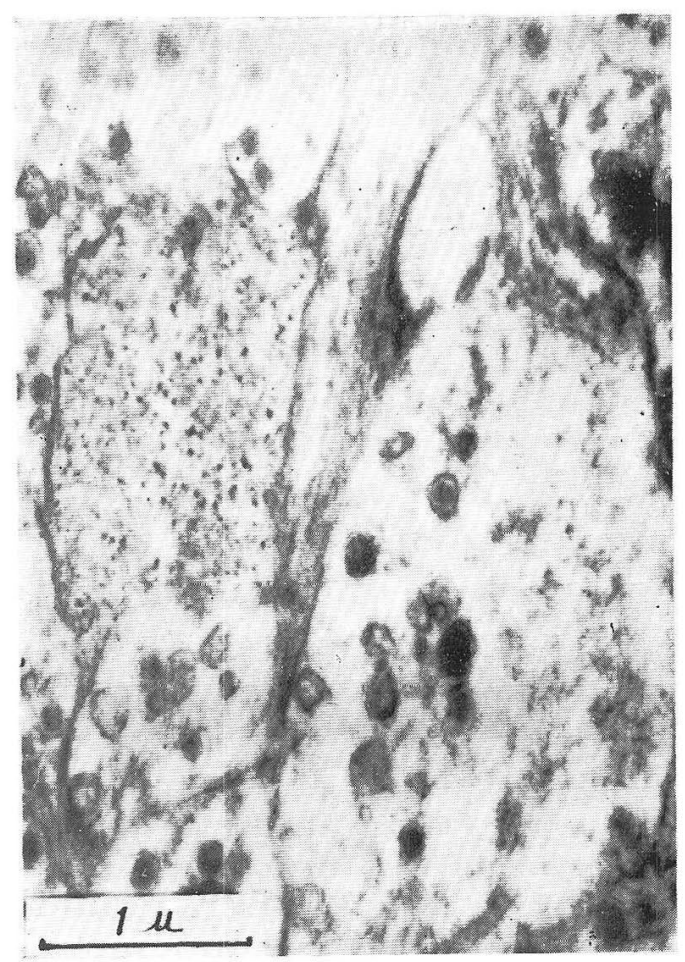

Fig. 3

plasmic movement, pushing aside the protoneurofibrils. The latter opinion is, though not definitely, supposed to be more correct.

Throughout the posterior lobc, many light areas surrounded by capsules as those shown in Fig. 1 may be seen. However, occasionally, some of the light areas inside the capsule are completely filled with the granules and consequently, its light tone is lost (Fig. 4). We consider such areas as HERRING's bodies. Since the discovery of the HERRING's body, a substance of apparently amorphous, hyaline composition, by HERRING (1908), considerable changes in the definition of HERRING's body ensued, owing to the advance in this field of investigation. If this be taken as a mass of neurosecretory substance, the mass of granules surrounded by the capsule may be considered as a HERRING's body. When stained with GOMORI's (CHP) method, the whole mass will be stained out as a mass of purple black, identical to the HERRING's body shown by the light microscope. The mass of granules is to be considered as a concentration of such granules seen in the light areas in Fig. 1. Whether this is in the exterior or interior of the nerve fiber is, in this 


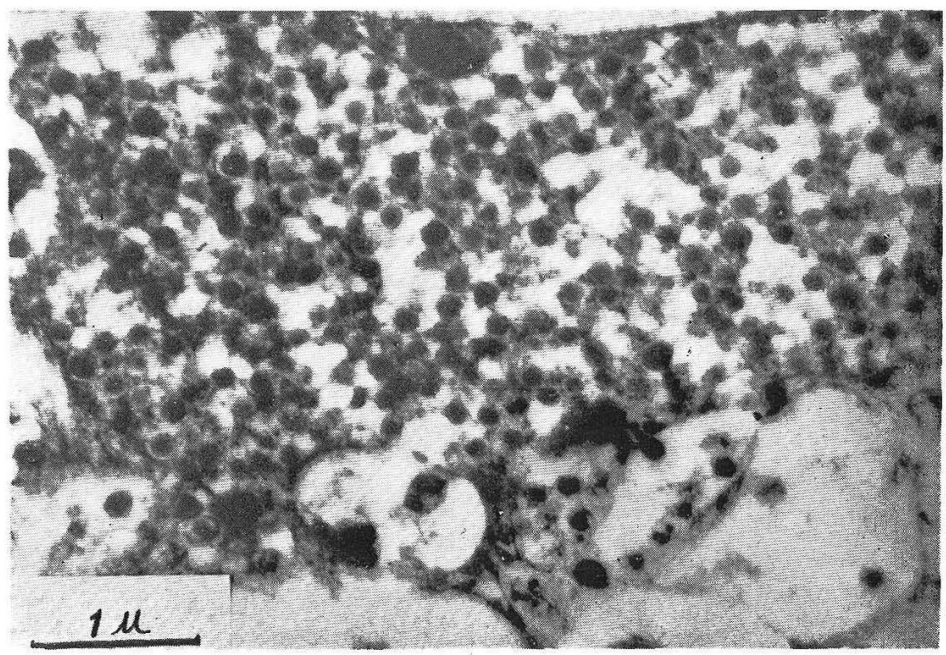

Fig. 4

case, unclear. As to the nature of the granules observed in the light areas surrounded by the capsule is a problem which remains to be solved. We have not performed any special experiments concerning this problem, but we assume from the reasons given below, that they are identical or closely related to the neurosecretory substance. The smallest unit of the gomoriphil granule seen with the light microscope, or the granules of the postcrior lobe seen with the phase contrast microscope is believed to be of nearly similar size with the granules detected by the electron microscope. The reason for comparing this with the smallest unit seen with the light microscope is that, with the GOMORI staining the concentrated granules are frequently found as a mass. The size of the smaller HERRING's body observed with the light microscope and that of the group of the granules shown in Fig. 4 are closely the same. GREEN and BREEMEN (1955) observed diminuition of these granules throughout the posterior lobe in animals made thirsty by the injection of saline solution. This coincides with the fact that the gomoriphil neurosecretory substance also decreases in the thirsting state.

These remarks lead to the assumption that this granule is identical or is in close relation to the neurosecretory substance.

\section{B. The size and structure of the granule.}

No marked difference is seen in the size of the granules throughout the posterior lobe, and its form is observed to be spherical. Under high power vision of $24,000 \times$, determination of diameters of 50 granules 
taken at randam from areas other than the HERRING's body surrounded by the capsule revealed the following results.

$100-150 \mathrm{~m} / \ell 28$ granules, $151-200 \mathrm{~m} / \mathrm{e} 16$ granules,

$201-250 \mathrm{~m} / \ell 5$ granules, $251-300 \mathrm{~m} \mu 1$ granule.

Thus they are distributed in $100-300 \mathrm{~m} \mu$, the size of most of them being around $150 \mathrm{~m} \mu$. These values were found to be close to those reported on various animals. In mammalia, reptilia and aves, it was observed to be $150-300 \mathrm{~m} / \ell$, (DUNCUN 1955), in rat, $100 \mathrm{~m} \mu$ (PALAY 1955) and in opposum, $1 / 10-1 / 6 \mu$ (GREEN and BREEMEN 1955).

In areas thought to be the HERRING's body where the granules are crowded together, the granules are somewhat smaller, the diameter being $80-170 \mathrm{~m} /$. This is believed to be due to the granules being pressed together.

Comparing these granules to the granules observed in the pituicytes of the posterior lobe, the latter were found to be of various sizes and forms according to the cell type in which they were located. The difference in size of granulcs in the pituicyte was found to be great, the diameter varying from 10 to $500 \mathrm{~m} \mu$. Some of the granules were solid, some vacuolated, some irregularly formed, some oval, some round, and some were found to be of minute particles. In contrast to this, those believed to be granules of neurosecretory substance were mostly in sizes of $100-300 \mathrm{~m} \mu$, with structures uniform as mentioned below and each spherically shaped. These may be evidence opposing the belief that neurosecretory granules are secreted from the pituicyte.

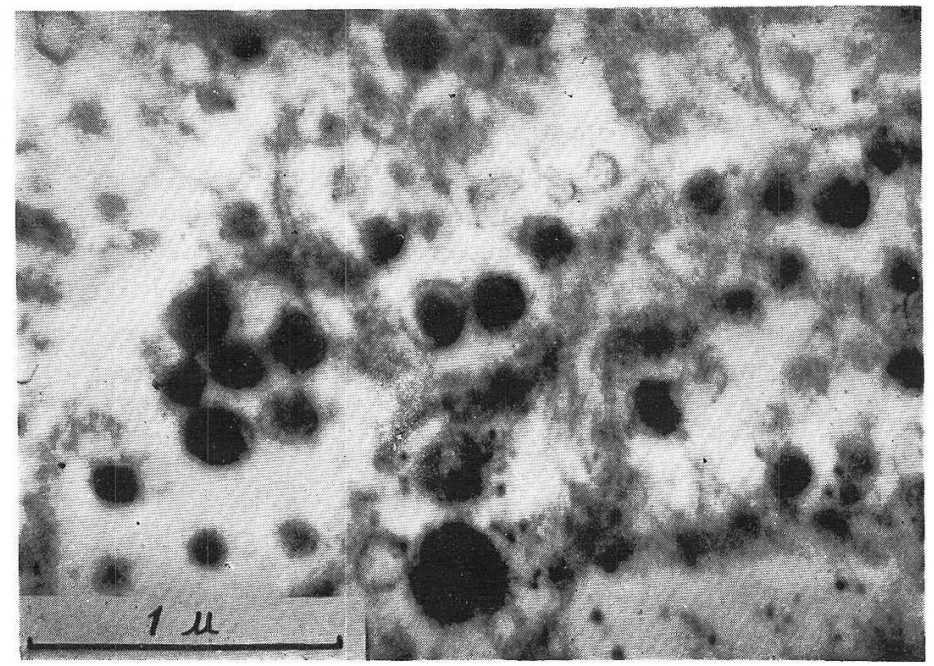

Fig. 5 
The granules in light areas were classified according to their structure into 3 types.

1. Granules with white halo burring of $100 \AA$ in thickness next to the boundary membrane. The central portion is dark, showing high electron density. 2. Granules with uniformly high electron density within the boundary membrane. 3. Granules with uniformly low electron density within the boundary membrane. But most of the granules were found to fall into type 1 . White halo burring can be seeu in granules shown in Figs. 3, 4 and 5. Granules observed next frequently were of type 2 , and the least, type 3 . Granules of these types may be seen diffusely distributed in Fig. 3. The relation between each type of granule is unknown.

All granules may have the structure of type 1 and may have acquired the forms of type 2 and 3 during the process of preparation. It has been reported by PALAY (1955) that granules of low electron density within the boundary membrane belonging to my type 3 appear in animals under thirsty condition.

The neurosecretory substance, previously thought to be of simply some glyco-lipo-protein-complex, has been demonstrated by BARRNETT and SELIGMAN (1952- 1954), SLOPER (1955) and IMOTO (1955) to be of a substance with the S-H radical and the S-S radical, i. e., a substance chiefly formed of cystin and cystein. We consider the portion with high electron density observed within the boundary membrane may be the portion formed chiefly with cystin and cystein.

\section{Summary.}

Electron microscopic observation was made on the pituitary posterior lobe of dog.

1. Round, oval or cylindrical, light-toned areas measuring $1-5 \mu$ in width with capsule of double membrane were seen in the posterior lobe of the hypophysis. A large number of small granules may be seen within these areas. Some of the capsules may be found in close contact with the pituicytes. The relation of these areas to the nerve fiber is still to be investigated, but some of them can be presumed to be in the nerve fiber.

2. Considering the size and the character of the granules, it is assumed that the granule is identical to the gomoriphil neurosecretory substance.

3. Occasionally, areas surrounded by capsule and filled with granules may be seen. These are assumed to be identical with the HERRING's body.

4. The granules are spherical with diameter of $100-300 \mathrm{~m} /$. Those 
observed within the HERRING's body have diameter of $80-150 \mathrm{~m} \mu$. Most of the granules have light halo burring in thickness of $100 \AA$ between the boundary membrane and the center portion of high electron density. Some of the granules lack the halo burring, with the central portion either high or low in electron density.

\section{内 容自 抄。}

成犬 5 例の後葉につき電子顕微鏡観察を行った，後葉にはいたるところ そ，2重葉性の膜に团まれた直径或は短径 I～5 多数の暗調の小顆粒が散在する所見が認められる（Fig. 1 と 2 ）。との明 調の小区域が神経線維の内部にあって，神経超原線維群の間を流れつ」あ る状態と考学られる所見もある (Fig. 3 右半)。しかし凡ての明るい小区 域が神経線維の内部であるか否かは断定出来ない，被膜に囲まれた小区域 の内部が明るくなくて，小顆粒の集団によって満たされている場合もある が，これは恐らく Herring 小体であるうと思われる（Fig. 4). 散在性 の小顆粒は略々球形であって, 直径 100- $200 \mathrm{~m} \mu$ のものが殆んどであり, Herring 小体を形成するすのではこれょりも幾分小さい.これらの顆粒は 限界膜の下に約 $100 \AA$ の白い量があってその内部が電子的密度の高い暗調 を呈するもの（Fig. 5) が最も多いが，限界膜の内部が一様飞電子的密度 の高いもの或は低いものもある。これらの顆粒は恐らく神経分泌物の基本 的単位粒子であり，限界膜内部の電子的密度の高い中核部は cystin 乃至 は cystein を主成分とする部分であろうと想像する。

\section{References.}

Barrnett, R. J. a. A. M. Seligman ; Science 116 (1952). P. 323. - J. nat. Cancer Inst. 14 (1954). P. 769. - Duncun, D.: Anat. Rec. 121 (1955). P. 430. - Goslar, H. G.: Acta neuroveg. 4 (1952). S. 25. - Acta neuroveg. 5 (1952). S. 381. - Goslar, H. G. u. F. Tischendorf : Z. mikr.-anat. Forsch. 61 (1955). S. 183. - Green, J. D. a. V. L. v. Breemen : Amer. J. Anat. 97 (1955). P. 177. - Hild, W. u. G. Zetler: Arch. exper. Path. u. Pharm. 213 (1951). S. 139. - Pflügers Arch. 257 (1953). S. 169. - Z. exp. Med. 120 (1953). S. 236. Hiraoka, S. u. T. Imoto: Arch. hist. jap. 7 (1955). S. 651. - (Jap. m. dtsch. Zfass.)- Imoto, T.: Arch. hist. jap. 8 (1955). S. 361 . (Jap. m. dtsch. Zfass.) - Palay, S. L.: Anat. Rec. 121 (1955). P. 348. - Schiebler, T. H.: Acta anat. 13 (1951). S. 233. - Acta anat. 15 (1952). S. 393. - Z. Zellforsch. 369 (1952). S. 563. - Sloper, J. C. : J. Anat. 89 (1955). P. 301. 